\title{
A Potential Asset of Proteasome Inhibitor Singly or Combined with Cisplatin Provides Inhibitory Effect on Human Gastric Cancer Cells
}

\section{Jie Jin ${ }^{1}$, Zhenzhen $\mathrm{Li}^{2}$, Honghua Ding ${ }^{2}$ and Dadao Jing ${ }^{2 *}$}

${ }^{1}$ Department of Gastroenterology, Branch of Shanghai General Hospital, Shanghai, China

${ }^{2}$ Department of Geriatrics and Gastroenterology, Shanghai General Hospital, Shanghai Jiaotong University, Shanghai, China

\section{Abstract}

Backgrounds and Objective: Proteasome inhibitors are a kind of novel anti-tumor agent which can inhibit cell growth and induce apoptosis by inhibiting the function of proteasome system and impacting the degradation of proteins related to cell growth or apoptosis. The aim of the study is to explore the effect of proteasome inhibitor Z-Leu-Leu-Phe-CHO (ZLLFC) singly or combined with cisplatin on proliferation or apoptosis of humnan gastric cancer cell SGC-7901, as well as its influence on the expression level of excision repair cross complementing 1(ERCC1) mRNA.

Metheds: MTT assay was used to calculate the growth inhibitory rate of human gastric cancer cell SGC7901. The apoptotic cell morphology was observed with electron microscopy, the apoptotic rate was analyzed by flow cytometry and by expression level of ERCC1 mRNA detected by RT-PCR.

Results: Proteasome inhibitor ZLLFC could inhibit the growth of gastric cancer cell SGC-7901. Combined application of proteasome inhibitor ZLLFC and cisplatin significantly increase the inhibitory effect on SGC-7901 cells, induced apoptosis and increased the apoptotic rate. While, the expression level of ERCC-1 mRNA in SGC-7901 cells in the combined group was significantly lower than that of the cisplatin group $(\mathrm{p}<0.01)$.

Conclusion: Proteasome inhibitor ZLLFC can inhibit the growth of gastric cancer cell SGC-7901. Combined application of ZLLFC and cisplatin can significantly increase the growth inhibiory effect and the apoptosis-promoting effect of gastric cancer cell SGC-7901.

\section{Introduction}

The highly conserved ubiquitin-proteasome system is the principal machinery for extralysosomal protein degradation in eukaryotic cells. The $26 \mathrm{~S}$ proteasome, a large multi-catalytic multi-subunit protease that processes cell proteins by limited and controlled proteolysis, constitutes the central proteolytic component of the ubiquitinproteasome system. By processing the cell proteins essential for the development, differentiation, proliferation, cell cycling, apoptosis, gene transcription, signal transduction, senescence, inflammatory and stress response, the $26 \mathrm{~S}$ proteasome plays a key role in the regulation and maintenance of basic cellular processes. Mutations or changes in these signaling pathways lead to defective transition from G2 to $S$ phase [1]. Given that ubiquitin-proteasome pathway affects multiple cellular process, its inhibition by proteasome inhibitor affects a broader spectrum of proteins with diverse functions. Proteasome inhibitors block protein degradation and cause accumulation of misfolded or damaged proteins, which in turn triggers heat shock response and cell death $[2,3]$. Furthermore, inhibition of the ubiquitin proteasome pathway (UPP) leads to significant buildup of cytotoxic proteins and activation of apoptotic pathways, particularly in rapidly proliferating cells. Therefore, proteasome inhibitor induces the accumulation of pro-apoptotic proteins in tumorigenic cells but not in the normal tissue [4].

Proteasome inhibitors have shown promising efficacy data in multiple myeloma (MM). Bortezomib, the first-in-class proteasome inhibitor, was subsequently approved by the United States Food and Drug Administration (FDA) as a first-line treatment for newly diagnosed MM patients and for the treatment of relapsed/refractory MM and mantle cell lymphoma[5]. In July 20, 2012, the FDA granted accelerated approval of carfilzomib, a second-generation proteasome inhibitor, for the treatment of relapsed/refractory $\mathrm{MM}$ in patients who have received at least 2 prior therapies[6].

\section{Publication History:}

Received: February 17, 2017

Accepted: August 09, 2017

Published: August 11, 2017

\section{Keywords:}

Proteasome inhibitor, Gastric Cancer, Z-Leu-Leu-Phe-CHO, Cisplatin, Apoptosis
It has been reported from non-clinical and clinical trials that proteasome inhibitors inhibit the growth of some solid tumors[3]. The observations from laboratory studies and clinical trials suggest that the anticancer potency for the treatment of solid tumors might be increased if proteasome inhibitor is combined with some conventional anticancer agents $[7,8]$. Gastric cancer is the second leading cause of death from malignant disease worldwide, with especially high mortality rates in the East, South, and Central Asia; Central and Eastern Europe; and South America [9]. Gastric cancers are most frequently discovered in advanced stages, and the prognosis of advanced gastric cancer remains poor because of limited treatment option. The killing effect of proteasome inhibitor on gastric cancer cells has seldom been studied. The objective of the present study is to explore the effect of proteasome inhibitor Z-Leu-Leu-Phe-CHO (ZLLFC) singly or combined with cisplatin on the proliferation or apoptosis of humnan gastric cancer cell SGC-7901, as well as its influence on the expression level of excision repair cross complementing 1(ERCC1) mRNA.

\section{Materials and Methods}

\section{Materials}

Proteasome inhibitor Z-Leu-Leu-Phe-CHO was purchased from Sigma Aldrich Chemical Company and dissolved in DMSO as

"Corresponding Author: Dr. Dadao Jing, Department of Geriatrics and Gastroenterology, Shanghai General Hospital, Shanghai Jiaotong University, Shanghai, China, E-mail: dadaojing@126.com

Citation: Jin J, Li Z, Ding H, Jing D (2017) A Potential Asset of Proteasome Inhibitor Singly or Combined with Cisplatin Provides Inhibitory Effect on Human Gastric Cancer Cells. Int J Gastroenterol Disord Ther 4: 129. doi: http://dx.doi. org/10.15344/2393-8498/2017/129

Copyright: (c) $2017 \mathrm{Jin}$ et al. This is an open-access article distributed under the terms of the Creative Commons Attribution License, which permits unrestricted use, distribution, and reproduction in any medium, provided the original author and source are credited. 
Citation: Jin J, Li Z, Ding H, Jing D (2017) A Potential Asset of Proteasome Inhibitor Singly or Combined with Cisplatin Provides Inhibitory Effect on Human Gastric Cancer Cells. Int J Gastroenterol Disord Ther 4: 129. doi: http://dx.doi.org/10.15344/2393-8498/2017/129

$1 \mathrm{mmol} / \mathrm{L}$ stock solution. Cisplatin was purchased from QiLu Pharmaceutical Plant. MTT was purchased from Sigma Aldrich Chemical Company. Annexin v-fitc/pi double-staining cell apoptosis kit was obtained from JingMei Bioengineering Limited Company. RTPCR kit was purchased from Fermentas Life Sciences Company. BD FACSCalibur ${ }^{\mathrm{TM}}$ System was obtained from BD Company.

\section{Cell culture}

SGC-7901 cells were purchased from Scientific Research institute of Chinese Academy of Science. The cells were cultured in RPMI 1640 medium (Hyclone Fisher Scientific International) supplemented with $10 \%(\mathrm{v} / \mathrm{v})$ heat inactivated newborn calf serum (Gibco Life Sciences) in a humidified atmosphere of $5 \% \mathrm{CO}_{2}$ and $95 \%$ air at $37^{\circ} \mathrm{C}$.

\section{Tetrazolium dye methylthiotetrazole (MTT) cytotoxicity assay}

SGC-7901 cells were seeded into 96-well microculture plates at $1 \times 10^{3}$ cells/well $(200 \mu \mathrm{l} /$ well $)$ and allowed to adhere for $24 \mathrm{~h}$. Then the cells were divided into 6 groups. Group 1 was the control group. The group 2 and 3 were exposed to $0.5 \mu \mathrm{mol} / \mathrm{L}$ and $1 \mu \mathrm{mol} / \mathrm{L}$ ZLLFC respectively. The group 4 was exposed to varying concentrations of cisplatin $(1 \mathrm{mg} / \mathrm{L}, \quad 0.5 \mathrm{mg} / \mathrm{L}, \quad 0.25 \mathrm{mg} / \mathrm{L}, \quad 0.125 \mathrm{mg} / \mathrm{L}, \quad 0.0625 \mathrm{mg} / \mathrm{L}$, $0.03125 \mathrm{mg} / \mathrm{L}$ ), and group 5 and 6 were exposed to cisplatin same as the group 4 , requiring concentrations of $0.5 \mu \mathrm{mol} / \mathrm{L}$ and $1 \mu \mathrm{mol} / \mathrm{L}$ ZLLFC added to these two group separately. The cells were then incubated for another $48 \mathrm{~h}$ or $72 \mathrm{~h}, 20 \mu \mathrm{l}$ of $5 \mathrm{mg} / \mathrm{ml}$ MTT was added to each well. The plates were incubated at $37^{\circ} \mathrm{C}$ for $4 \mathrm{~h}$ and the medium was replaced with $100 \mathrm{ml}$ of DMSO. The absorbance in the control and the drug-treated wells were measured at $490 \mathrm{~nm}$ for absorbancy(A value) using microplate reader. Cell viability $(\%)=[($ A value of experimental group-A value of backgound)/(A value of control group-A value of backgound) $] \times 100 \%$. Each experimental data point represents the average value obtained from six replicates, and each experiment was repeated three times.

\section{Electron microscopy}

SCG-7901 cells in log growth phase were digested and adjusted at a cell concentration of $5 \times 10^{6} / \mathrm{L}$, then seeded onto 6-well microculture plates. After allowance to adhere for $24 \mathrm{~h}$, the cells were divided into 4 groups including control group, $1 \mu \mathrm{mol} / \mathrm{L}$ ZLLFC group, $1 \mathrm{mg} / \mathrm{L}$ cisplatin group, combined $1 \mu \mathrm{mol} / \mathrm{L}$ ZLLFC and $1 \mathrm{mg} / \mathrm{L}$ cisplatin group. Each group was exposed to the corresponding drug at the above concentrations. After incubated for another $24 \mathrm{~h}$, the cells were fixed by glutaraldehyde and osmium tetroxide, dehydrated by ethanol and acetone, and embedded in epoxy resin. Thin sections were stained in uranyl acetate and lead citrate, and examined under transmission electron microscope.

\section{Quantification of apoptosis}

The group division and drug explosure were as the same as that for electron microscopy. The cells were collected, washed in phosphate buffered saline (PBS) and stained by Annex-V and propidium iodide(PI). The samples were then analyzed by fluorescence-activated cell sorting (FACS)

\section{RT-PCR (reverse transcription PCR) analysis}

SCG-7901 cells in the log growth phase were digested and seeded onto 6-well microculture plates. After allowed to adhere for $24 \mathrm{~h}$, the cells were divided into 4 groups including the control group, $1 \mathrm{mg} / \mathrm{L}$ cisplatin group. Each group was exposed to the corresponding drug to the above concentration. After incubated for another $24 \mathrm{~h}$, total RNA was extracted. Reverse transcription was performed by reverse transcriptase kit. The resulting cDNA was subjected to the PCR-based amplification with the following oligonucleotides: for ERCC-1, 5'-GGCGACGTAATCCCGACTA-3' and 5'-AGTCTCCCCAGGCTCTGC-3'; for $\beta$-actin, 5'-GTGGG GCGCCCCAGGCACCA-3' and 5'-CTTCCTTAATGTCACGCAC GATTTC-3'. PCR was performed under the following conditions: $5 \mathrm{~min} 95^{\circ} \mathrm{C}$ preincubation, followed by 30 cycles of denaturation $(45 \mathrm{~s}$, $94^{\circ} \mathrm{C}$ ), annealing $\left(45 \mathrm{~s}, 58^{\circ} \mathrm{C}\right)$, and extension $\left(1 \mathrm{~min}, 72^{\circ} \mathrm{C}\right)$, followed by a final extension of $10 \mathrm{~min}$ at $72^{\circ} \mathrm{C} .5 \mu \mathrm{l}$ PCR products were mixed with $1 \mu \mathrm{l} 6 \times$ Loading dye Solution and then electrophoresed with DNA marker, followed by visualization by gel imaging system from Alpha Company. Each experiment was repeated three times.

\section{Statistic analysis}

All the descriptive data was expressed by mean \pm standard deviation. Statistical analyses were performed using SPSS 11.0. Student's t-test was used to compare the difference between the two groups and Dunnet-test (ANOVE) was used to compare the difference among three groups respectively. $\mathrm{P}$ value of less than 0.05 was considered statistically significant.

\section{Results}

\section{Cell viability of SGC-7901 cells treaded by ZLLFC and cisplatin}

As shown in Figure 1, cell viability of group 2 or 3 was lower than group 1 (control group) $(\mathrm{p}<0.01)$ in a time-dependent manner,but there's no significant difference between group 2 or 3 . As shown in Figure 2 and Figure 3, cisplatin reduced proliferation of SGC7901 cells in a dose- and time-dependent manner. Also in Figure 2 and Figure 3, the cell viability of group 5 and 6 indicated that the combined cisplatin and ZLLFC induced more significant inhibitory effect on SGC-7901 cells than that by cisplatin singly, whereas, 0.5 $\mu \mathrm{mol} / \mathrm{L}$ or $1 \mu \mathrm{mol} / \mathrm{L}$ ZLLFC showed the approximately synergistic action with cisplatin in the inhibitory effect on SGC-7901 cell growth.

\section{Morphology of SGC-7901 cells treated with ZLLFC and cisplatin}

SGC-7901 cells showed normal morphology at normal culture condition by transmission electron microscope (Figure 4a). Treated with $1 \mu \mathrm{mol} / \mathrm{L}$ ZLLFC or $1 \mathrm{mg} / \mathrm{L}$ cisplatin, the cells showed mild apoptotic changes: a few cytoplasmic vacuoles, mild cell shrinkage, increased cell density (Figure 4b, Figure 4c). Combined application of $1 \mu \mathrm{mol} / \mathrm{L}$ ZLLFC and $1 \mathrm{mg} / \mathrm{L}$ cisplatin caused typical apoptosis features on SGC-7901 cells: cell shrinkage, nuclear condensation and chromatin condensation, crescent nucleus, apoptotic bodies aggregated adjacent to the cell membrane, as well as to complete nuclear and cell membrane(Figure 4d).

\section{Apoptotic rate of SGC-7901 cells induced by ZLLFC and cisplatin}

The apoptotic rates of the control group, ZLLFC group, cisplatin group, and combined group were $(0.047 \pm 0.025) \%(4.37 \pm 3.00) \%$ $(11.78 \pm 2.85) \%(23.94 \pm 2.22) \%$ respectively. The apoptosis rate of the combined group was significantly higher than that of ZLLFC group or cisplatin group $(\mathrm{P}<0.01) \mathrm{P}<0.01)$ (Figure 5a-Figure $5 \mathrm{~d}$ ). 
Citation: Jin J, Li Z, Ding H, Jing D (2017) A Potential Asset of Proteasome Inhibitor Singly or Combined with Cisplatin Provides Inhibitory Effect on Human Gastric Cancer Cells. Int J Gastroenterol Disord Ther 4: 129. doi: http://dx.doi.org/10.15344/2393-8498/2017/129

Page 3 of 6



\section{The ERCC1 mRNA expression level on SGC-7901 cells induced by ZLLFC and cisplatin}

The optical density value of ERCC1mRNA in cisplatin group was $717.33 \pm 29.17$ (Figure 6, lane C,D), much higher than that of the control group (lane $A, B, 570.83 \pm 20.76)(p<0.01)$. The optical density values of the two combined groups were $297.33 \pm 12.93$ (lane E,F treated with $0.5 \mu \mathrm{mol} / \mathrm{L} Z \mathrm{LLFC}$ and $1 \mathrm{mg} / \mathrm{L}$ cisplatin) and $284.83 \pm 24.80$ (lane $\mathrm{G}, \mathrm{H}$, treated with $1 \mu \mathrm{mol} / \mathrm{L}$ ZLLFC and $1 \mathrm{mg} / \mathrm{L}$ cisplatin), which were significantly lower than that of the cisplatin $\operatorname{group}(\mathrm{p}<0.01)$, but there was no statistical difference between the two combined groups $(\mathrm{p}>0.05)$.

\section{Discussion}

Proteasome inhibitors are a kind of novel anti-tumor agent which can inhibit cell growth and induce apoptosis by inhibiting the function of proteasome system, impacting the degradation of proteins related to cell growth or apoptosis. The first approved proteasome inhibitor, bortezomib belongs to boron-containing compounds, and MG132 is from aldehyde-containing compounds. Bontizomib with its brand name as Velcade has provided promising efficacy data on hematologic malignancies such as MM and mantle cell lymphoma. $[5,10,11]$ MG132 induces apoptosis potentially through the following pathways: formation of reactive oxygen species (ROS), cooperation with APO2L or tumor necrosis factor (TNF)-related apoptosis inducing legand(TRAIL), trimerization of HSF1, NF-KB inhibition, or P53-indepentdent pathway $[12,13]$. 
Citation: Jin J, Li Z, Ding H, Jing D (2017) A Potential Asset of Proteasome Inhibitor Singly or Combined with Cisplatin Provides Inhibitory Effect on Human Gastric Cancer Cells. Int J Gastroenterol Disord Ther 4: 129. doi: http://dx.doi.org/10.15344/2393-8498/2017/129
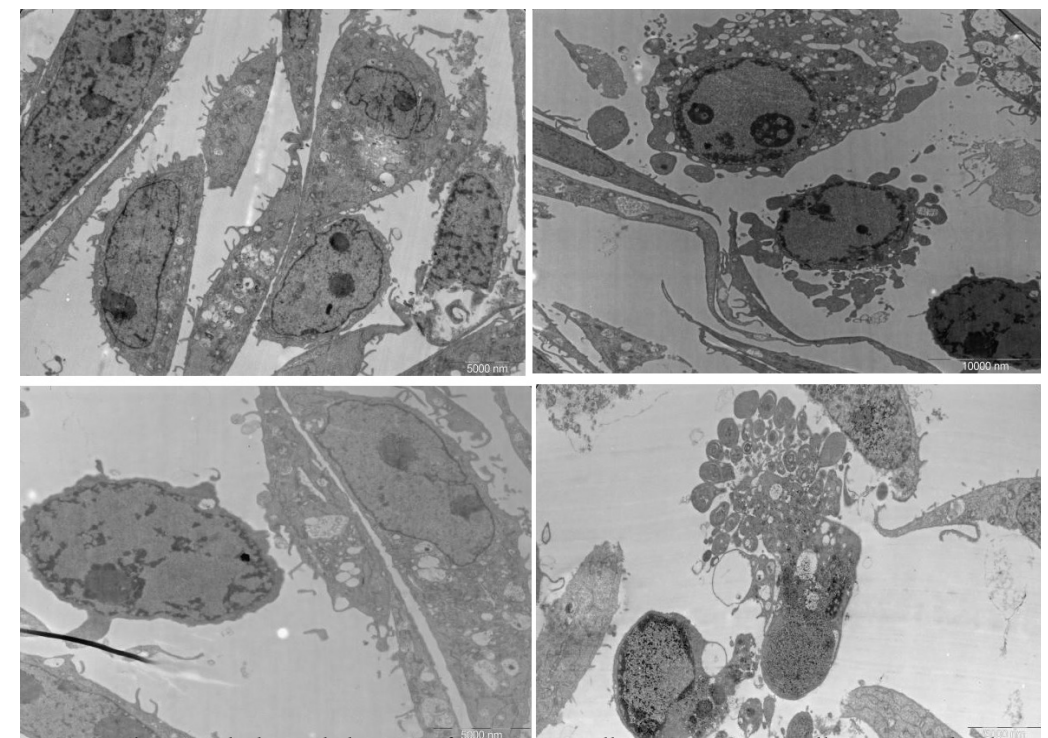

Figure 4: The morphological changes of SGC-7901 cells. A. SGC-7901 cells in normal culture condition. B. SGC-7901 cells treated with $1 \mu \mathrm{mol} / \mathrm{L}$ ZLLFC. C. SGC-7901 cells treated with $1 \mathrm{mg} / \mathrm{L}$ cisplatin. D. SGC-7901 cells treated with $1 \mu \mathrm{mol} / \mathrm{L}$ ZLLFC and $1 \mathrm{mg} / \mathrm{L}$ cisplatin.
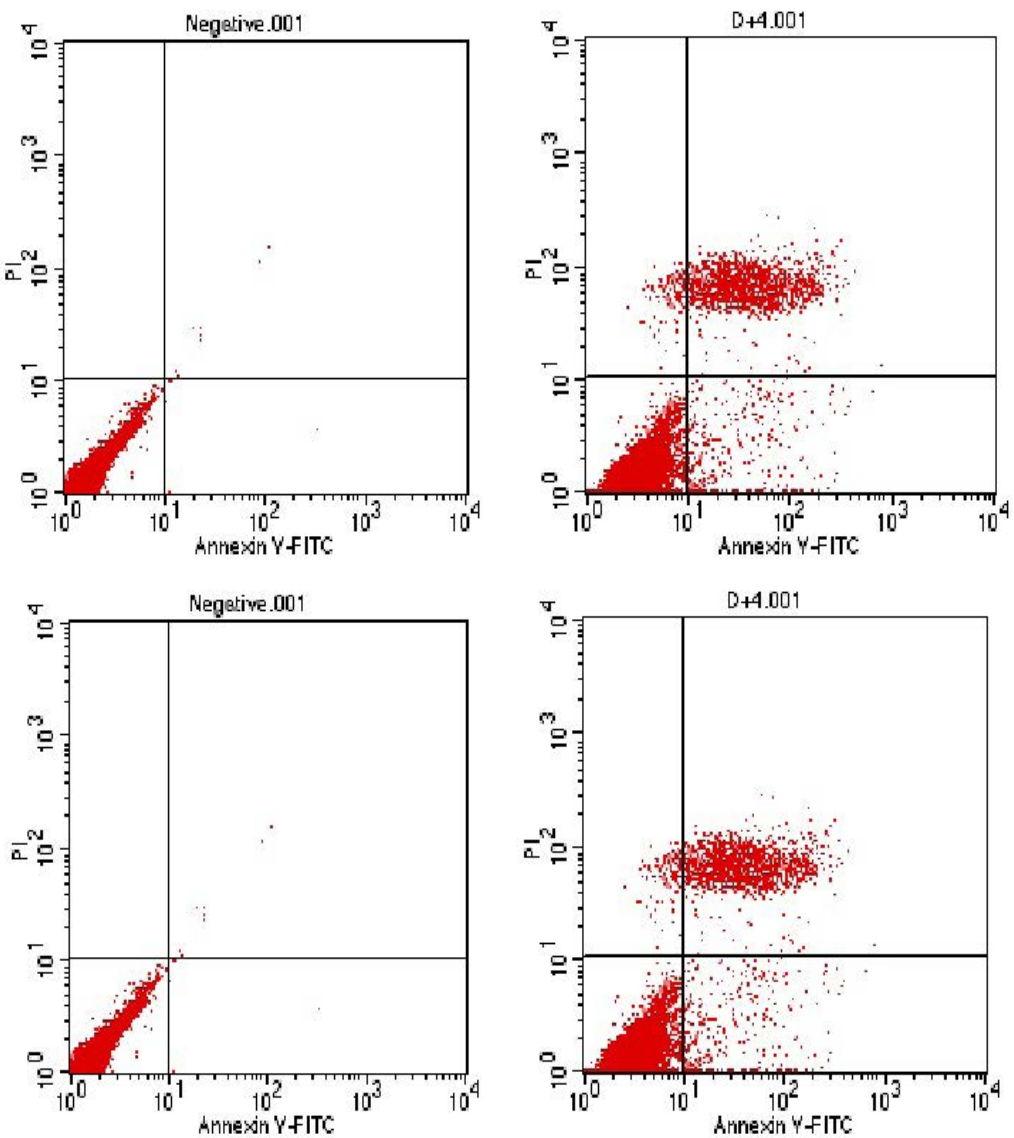

Figure 5: Apoptotic rates of SGC-7901 cells were analyzed by flow cytometry. (a) SGC-7901 cells in normal culture condition. (b) SGC-7901 cells treated with $1 \mu \mathrm{mol} / \mathrm{L}$ ZLLFC. (c) SGC-7901 cells treated with $1 \mathrm{mg} / \mathrm{L}$ cisplatin. (d) SGC-7901 cells treated with $1 \mu \mathrm{mol} / \mathrm{L}$ ZLLFC and $1 \mathrm{mg} / \mathrm{L}$ cisplatin. The points at the right lower quadrant (Annexin $-\mathrm{V}$ positive staining and PI negative staining) refer to the apoptotic cells. The points at the right upper quadrant (Annexin-V/PI double positive staining) refer to the necrotic cells. The apoptosis rate of the combined group was significantly higher than that of the ZLLFC group or cisplatin group, $\mathrm{P}<0.01$. 


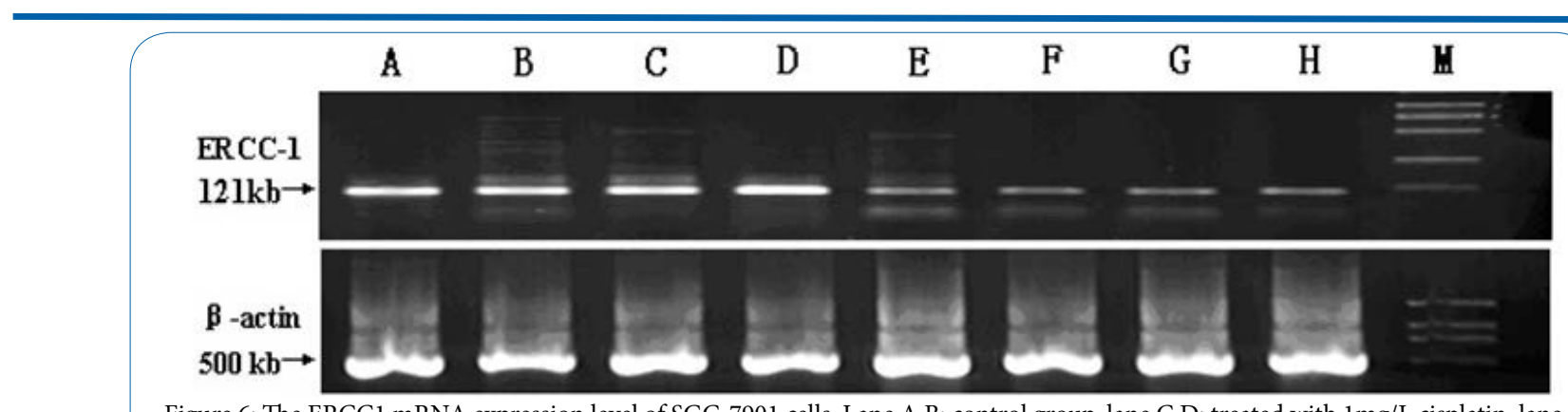

Figure 6: The ERCC1 mRNA expression level of SGC-7901 cells. Lane A,B: control group, lane C,D: treated with 1mg/L cisplatin, lane E,F: treated with $0.5 \mu \mathrm{mol} / \mathrm{L}$ ZLLFC and $1 \mathrm{mg} / \mathrm{L}$ cisplatin, lane G,H: treated with $1 \mu \mathrm{mol} / \mathrm{L}$ ZLLFC and $1 \mathrm{mg} / \mathrm{L}$ cisplatin. The optical density values of lane $C, D$ was much higher than that of lane $A, B, P<0.01$; The optical density values of lane E,F,G,H, were significantly lower than those of cisplatin group $\mathrm{P}<0.01$; there was no statistical difference between the two combined groups, $\mathrm{P}>0.05$.

Although bontizomid and carfilzomib have been proved effective in clinical trials and clinical practice, many disadvantages still exist owing to its severe side effects such as decreased efficacy toward solid tumors, interactions with numerous natural products and acquisition of drugresistance in a large portion of cancer patients. The most frequent side effects (incidence $>30 \%$ ) were associated with bortezomib in clinical trials including asthenic conditions such as fatigue, generalized weakness, gastrointestinal symptoms (nausea, vomiting, diarrhea, etc.), hematological toxicity, peripheral neuropathy characterized by decreased sensation, paresthesia and high rate of shingles [12]. In terms of drug-resistance, bortezomib has been reported to have up to $88 \%$ response rate, but about $60 \%$ of the patients treated with bortezomib develop resistance within an average of one year from the initial treatment $[14,15]$. Carfilzomib, a "second-generation" proteasome inhibitor, was developed to address bortezomib's toxicity and drug resistance while achieving comparable potency [16]. These findings encourage basic research to develop newer generation proteasome inhibitors that would broaden the spectrum of activity including as targeting to solid tumor, produce more durable clinical response and more potentiating what to combined with conventional treatment, as well as to provide improved safety profile.

The proteasome inhibitor Z-Leu-Leu-Phe-CHO (ZLLFC) used in our study also belongs to aldehyde-peptides and has similar structure with MG132. Proteasome inhibitors can influence the NF- $\kappa b$ and ERK/ MAPK signal transduction pathway, cell cycle related protein p27kip1 as well as Bcl-2 protein family. Therefore, preteasome inhibitors have the potential to reverse the anti-apoptosis effect initiating by chemotherapeutic agents and become multi-drug resistance(MDR) reversal agents $[17,18]$. The clinical trials according to the therapeutic function of proteasome inhibitor on solid tumors such as lymphoma, lung cancer, pancreas cancer, gastric cancer,etc. are ongoing.

With MTT cytotoxicity assay, electron microscopy and quantification of apoptosis, our study showed that proteasome inhibitor ZLLFC used singly could inhibit the growth of gastric cancer cell SGC-7901, induce them into early apoptosis, while, there's no significant difference in promoting apoptosis effect between $0.5 \mu \mathrm{mol} / \mathrm{L}$ and $1 \mu \mathrm{mol} / \mathrm{L}$ ZLLFC( $>0.05)$. MTT cytotoxicity assay indicated cisplatin could reduce proliferation of SGC-7901 cells in a dose-dependent manner. Combined ZLLFC and cisplatin of different concentration gradient showed lower cells viability than cisplatin used singly. Meanwhile, the growth inhibitory effect in the combined group have a time-dependent manner, ie, drug action of 62 hours showed stronger effect than that of 48 hours. With $0.5 \mu \mathrm{mol} / \mathrm{L}$ or $1 \mu \mathrm{mol} / \mathrm{L}$ ZLLFC, the combined group showed inhibitory effect to the same extent. These results suggested the cytotoxic effect of ZLLFC on
SGC-7901 cells. When combined with cisplatin, ZLLFC increased the cytotoxicity and promoting apoptosis effect of cisplatin in a timedependent manner ,to achieve the best concentration would needd more investigation.

Cisplatin is a wildly used anti-tumor agent, it damages DNA and inhibits DNA replication by cisplatin-DNA adduct. Cisplatin used singly is liable to induce drug resistance,one of the major mechanisms of drug resisitance induced by cisplatin is injured DNA-strand incision [19]. ERCC1(excision repair cross complementing 1) is a NER(nucleotide excision repair) component that participates in DNA damage recognition and DNA strand incision. ERCC1 plays an importantrole in the repair of damaged DNA and maintaining the integeity of genetic information. The inhibition of ERCC1 expression by antisense approaches has been reported to reduce cisplatin-DNA adduct repair [20]. In human ovarian and gastric cancer, elevated ERCC1 mRNA expression in the tumor tissue has been related to increase cisplatin resistance [21,22]. Overexpression of ERCC1 has also been associated with resistance to cisplatin in human hepatocellular carcinoma [23]. Li Y, et al. treated gastric cancer cells withlactacystin and Mimnaugh EG, et al. treated ovarian carcinoma cells with combination of cisplatin and proteasome inhibitor lactacystin(LC) or $\mathrm{N}$-acetyl-leucyl-leucyl-norleucinal (ALLnL),both proteasome inhibitors prevented the increase in ERCC1 mRNA expression that occured in cells exposed to cisplatin [24,25]. Low ERCC1 is candidate for predictive biomarkers for first-line in advanced gastric cancer [26] and patients who suffer from gastric cancer with ERCC1-negative expression could benefit more from adjuvant chemotherapy [27]. Our study also indicated an increase of ERCC1 mRNA expression in SGC-7901 cells when exposed to cisplatin. But combined ZLLFC and cisplatin significantly decreased the ERCC1 mRNA expression in comparison with cisplatin used singly $(\mathrm{p}<0.01)$. This result suggested ZLLFC could prevent the up-regulation of ERCC1 transcription level and might be a good treatment in gastric cancer.

The discovery of less toxic and novel proteasome inhibitors may provide more viable drug candidates for the treatment of cancer patients in the future. Our study indicated a novel drug candidate of proteasome inhibitor, Z-Leu-Leu-Leu-CHO(ZLLFC), could induce SGC-7901 cells apoptosis. ZLLFC reversed the drug resistance of cisplatin by down-regulating ERCC1 transcription level, which is the key point of cisplatin-DNA adduct incision. Throughout the study, there was no significant difference between $0.5 \mu \mathrm{mol} / \mathrm{L}$ and $1 \mu \mathrm{mol} / \mathrm{L}$ ZLLFC. More research in vitro studies with different tumor cell lines and animal models should be warranted to offer adequate basic research data to pursue potential clinical development for this asset in the future. 
Citation: Jin J, Li Z, Ding H, Jing D (2017) A Potential Asset of Proteasome Inhibitor Singly or Combined with Cisplatin Provides Inhibitory Effect on Human Gastric Cancer Cells. Int J Gastroenterol Disord Ther 4: 129. doi: http://dx.doi.org/10.15344/2393-8498/2017/129

Page 6 of 6

\section{Acknowledgments}

Thanks to Dr. Zhang QH (Shanghai Biochip Co., Ltd.) and his team for their expert technical assistance. We are also grateful to Dr.Wu XN to revise this article. The English version in this document has been checked by at least two professional editors, both native speakers of English,we give our thankfulness to them.

\section{Competing Interests}

The authors have declared that no competing interest exists.

\section{References}

1. Elliott PJ, Ross JS (2001) The proteasome: a new target for novel drug therapies. Am J Clin Pathol 116: 637-646.

2. Naujokat C, Fuchs D, Berges C (2007) Adaptive modification and flexibility of the proteasome system in response to proteasome inhibition. Biochim Biophys Acta 1773: 1389-1397.

3. Redzic JS, Gomez JD, Hellwinkel JE, Anchordoquy TJ, Graner MW (2016) Proteomic analyses of brain tumor cell lines amidst the unfolded protein response. Oncotarget 267: 47831-47847.

4. Yang P, Li ZY, Li HQ (2015) Potential Roles of Protease inhibitors in cancer progression . Asian Pac J Cancer Prev16: 8047-8052.

5. Chen D, Frezza M, Schmitt S, Kanwar J, Dou QP (2011) Bortezomibas the first proteasome inhibitor anticancerdrug: current status and future perspectives. Curr Cancer Drug Targets 11: 239-253.

6. Herndon TM, Deisseroth A, Kaminskas E, Kane RC, Koti KM, et al. (2013) U.s. Food and Drug Administration approval: carfilzomib for the treatment of multiple myeloma. Clin Cancer Res 19: 4559-4563.

7. Badros A, Burger AM, Philip S, Niesvizky R, Kolla SS, et al. (2009) Phase I study of vorinostat in combination withbortezomibfor relapsed and refractory multiple myeloma. Clin Cancer Res 15: 5250-5257.

8. Turkington RC, Purcell C, James CR, Millar J, Napier E, et al. (2014) Aphase I trial of bortezomib in combination with epirubicin, carboplatin and capecitabine (ECarboX) in advanced oesophagogastric adenocarcinoma. Invest New Drugs 32: 250-260.

9. Ferlay J, Shin HR, Bray F, Forman D, Mathers C, et al. (2010) Estimates of worldwide burden of cancer in 2008: GLOBOCAN 2008. Int J Cancer 127: 2893-2917.

10. Wright JJ (2010) Combination therapy of bortezomib with novel targeted agents: an emerging treatment strategy. Clin Cancer Res 16: 4094-4104.

11. Ma Y, Chen B, Liu D, Yang Y, Xiong Z, et al. (2011) MG132 treatment attenuates cardiac remodeling and dysfunction following aortic banding in rats via the NF-kB/TGFb1 pathway. Biochem Pharmacol 81: 1228-1236.

12. Guo N, Peng Z (2013) MG132, a proteasome inhibitor, induces a poptosis in tumor cells. Asia Pac J Clin Oncol 9: 6-11.

13. Fan WH, Hou Y, Meng FK, Wang XF, Luo YN, et al. (2011) Proteasome inhibitor MG-132inducesC6 glioma cellapoptosisvia oxidative stress. Acta Pharmacol Sin 32: 619-625

14. Dou QP, Zonder JA (2014) Overview of proteasome inhibitor-based anticancer therapies: perspective on bortezomib and second generation proteasome inhibitors versus future generation inhibitors of ubiquitinproteasome system. Curr Cancer Drug Targets 14: 517-536.

15. Mujtaba T, Dou Q (2011) Advances in the understanding of mechanisms and therapeutic use of bortezomib. Discov Med 12: 471-480.

16. Fostier K, De Becker A, Schots R (2012) Carfilzomib: a novel treatment in relapsed and refractory multiple myeloma. Onco Targets Ther 5: 237.

17. Kisselev AF, van der Linden WA, Overkleeft HS (2012) Proteasome inhibitors:an expanding army attacking a unique target. Chem Biol 19: 99115.

18. Panischeva LA, Kakpakova ES, Rybalkina EY, Stavrovskaya AA (2011) Influence of proteasome inhibitor bortezomib on the expression of multidrug resistance genes and Akt kinase activity. Biochemistry (Mosc) 76: 1009-1016
19. O'Grady S, Finn SP, Cuffe S, Richard DJ, O'Byrne KJ, et al. (2014) The role of DNA repair pathways in cisplatin resistant lung cancer. Cancer Treat Rev 40: 1161-1170.

20. Martin LP, Hamilton TC, Schilder RJ (2008) Platinumresistance: the role of DNA repair pathways. Clin Cancer Res 14: 1291-1295.

21. Smith S, Su D, Rigault de la Longrais IA, Schwartz P, Puopolo M, et al (2007) ERCC1genotype and phenotype in epithelial ovarian cancer identify patients likely to benefit from paclitaxel treatment in addition to platinumbased therapy. J Clin Oncol 25: 5172-5179.

22. Li W, Jie Z, Li Z, Liu Y, Gan Q, Mao Y, et al. (2014) ERCC1siRNA ameliorates drug resistance to cisplatin in gastric carcinoma cell lines. Mol Med Rep 9: 2423-2428.

23. Ueda S, Shirabe K, Morita K, Umeda K, Kayashima H, et al. (2011) Evaluation of ERCC1expression for cisplatin sensitivity in human hepatocellular carcinoma. Ann Surg Oncol 18: 1204-1211.

24. Li Y, Gao H, Wang Y, Dai C (2015) Investigation the mechanism of the apoptosis induced by lactacystin in gastric cancer cells. Tumour Biol 36 : 3465-3470.

25. Mimnaugh EG, Yunmbam MK, Li Q, Bonvini P, Hwang SG, et al. (2000) Prevention of cisplatin-DNA adduct repair and potentiation of cisplatininduced apoptosis inovariancarcinoma cells by proteasome inhibitors. Biochem Pharmacol 60: 1343-1354

26. Tsuburaya A, Sugimoto $\mathrm{N}$, Imamura $\mathrm{H}$, Nishikawa $\mathrm{K}$, Imamoto $\mathrm{H}$, et al (2016) Molecular Biomarker Study in a Randomised Phase III Trial of Irinotecan Plus S-1 versus S-1 for Advanced Gastric Cancer (GC0301/ TOP-002). Clin Oncol (R Coll Radiol) 28: e45-51.

27. Wang J, Zhou XQ, Li JY, Cheng JF, Zeng XN, et al. (2014) Prognostic significance of ERCC1 expression in postoperative patients with gastric cancer. Chine J Cancer Res 26: 323-330. 